\title{
Reconstruction of the 1945 Wieringermeer Flood
}

\section{O. A. C. Hoes ${ }^{1}$, R. W. Hut ${ }^{1}$, N. C. van de Giesen ${ }^{1}$, and M. Boomgaard ${ }^{2}$ \\ ${ }^{1}$ Faculty of Civil Engineering and Geo Sciences, Delft University of Technology, Delft, The Netherlands \\ ${ }^{2}$ Water Board Hollands Noorderkwartier, Heerhugowaard, The Netherlands}

Received: 19 February 2013 - Accepted: 22 February 2013 - Published: 11 March 2013

Correspondence to: O. A. C. Hoes (o.a.c.hoes@tudelft.nl)

Published by Copernicus Publications on behalf of the European Geosciences Union.

\section{Reconstruction of the 1945 \\ Wieringermeer Flood \\ O. A. C. Hoes et al.}

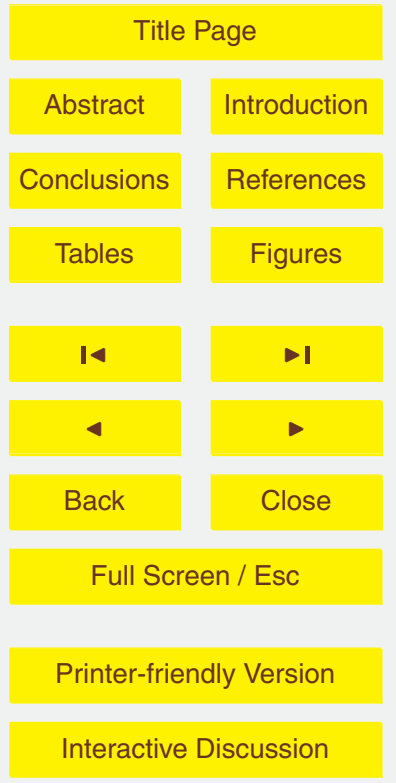




\section{Abstract}

The present state-of-the-art in flood risk assessment focuses on breach models, flood propagation models, and economic modelling of flood damage. However, models need to be validated with real data to avoid erroneous conclusions. Such reference data can either be historic data, or can be obtained from controlled experiments. The inundation of the Wieringermeer polder in the Netherlands in April 1945 is one of the few examples for which sufficient historical information is available. The objective of this article is to compare the flood simulation with flood data from 1945. The context, the breach growth process and the flood propagation are explained. Key findings for current flood risk management addresses the importance of the drainage canal network during the inundation of a polder, and the uncertainty that follows from not knowing the breach growth parameters. This case study shows that historical floods provide valuable data for the validation of models and reveal lessons that are applicable in current day flood risk management.

\section{Introduction}

Predicting how an embankment fails, how the adjacent area fills up with flood water and estimating the damage involved, are essential parts of a flood risk assessment. The importance of understanding these three issues can be illustrated by the recent floods in Pakistan in 2010 and 2011 (Tariq and Giesen, 2011). The present state-ofthe-art focuses on breach models, flood propagation models, and economic modelling of flood damage (Apel et al., 2004, 2006, 2009; Manen and Brinkhuis, 2005; Bouwer et al., 2009). However, models need to be validated with real data to avoid erroneous conclusions and the implementation of unsatisfactory measures. Such real data can either be historical data, or can be obtained from controlled experiments. Full-scale experiments are difficult and expensive to accomplish. Experiments on a small scale are problematic because results cannot be extrapolated to large areas. Accurate historical

\section{NHESSD}

$1,417-441,2013$

\section{Reconstruction of the 1945}

Wieringermeer Flood

O. A. C. Hoes et al.

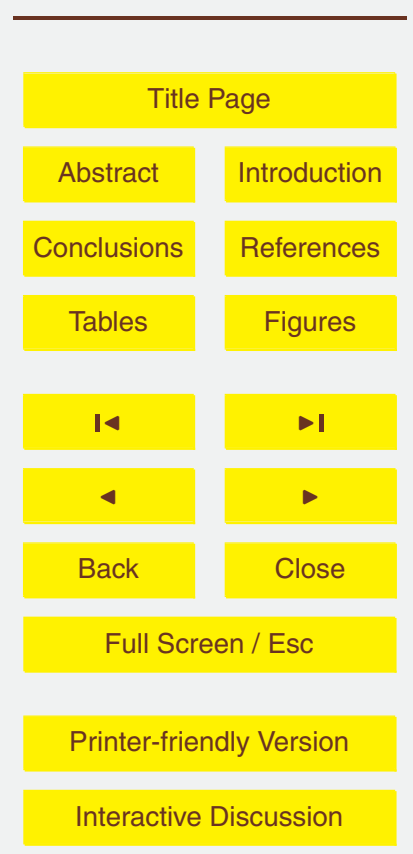


data for validation are hard to get, even in the Netherlands with its long history of floods. During large disasters - as the February 1953 flood - everyone is busy saving his or her loved ones and belongings, instead of collecting data.

Sometimes, historical data can be obtained by retrospective analysis. Jelgerma et al. 5 (1995) used geological records to reconstruct surge heights of pre-historic storms. Gottschalk (1977) used written records and artwork to construct an overview of all floods from the 14th until 18th century in the Netherlands. More recently, Baart et al. (2011) used 18th century paintings and drawings to estimate storm surge levels. Lumbroso and Vinet (2011) compared the February 1953 flood in England with coastal 10 flooding in France in 2010. However, none of these reconstructed floods were sufficient to validate a flood model.

In our search for a proper dataset to validate a polder flood, we found one case for which the necessary information is as complete as one would like. In 1945 the Wieringermeer polder area was flooded deliberately by the German armed forces

\section{about three weeks before the end of World War II. The 118000 German occupying} troops in the Netherlands controlled the western provinces in Festung Holland, but were enclosed by Allied Forces. To prevent the Allied Forces to enter Festung Holland through the Afsluitdijk from the north, the Germans blew up the embankment at two locations that separated the Wieringermeer polder from Lake IJssel. As the Allied Forces did not even attempt taking this route, one may qualify the Wieringermeer inundation as an act of despair instead of a military-strategic necessity. The water level at Lake IJssel was $0.12 \mathrm{~m}$ above mean sea level (m.s.l.), and the surface level adjacent to the location of the blast was $3.5 \mathrm{~m}$ below m.s.l. At the start of the prospective $48 \mathrm{~h}$, the water seeped through the two grooves formed by the explosions, but as these grooves developed further, the polder was flooded by a wall of water.

Historic information from this inundation was reported in detail and is still available in different archives in the Netherlands, such as the archive of the Dutch Ministry of Infrastructure and the Environment, the Noord Hollands Archive in Haarlem, Regional Archive in Alkmaar, the Nieuwland Erfgoed Centre in Lelystad, and the NIOD Institute in

\section{NHESSD}

$1,417-441,2013$

Reconstruction of the 1945

Wieringermeer Flood

O. A. C. Hoes et al.

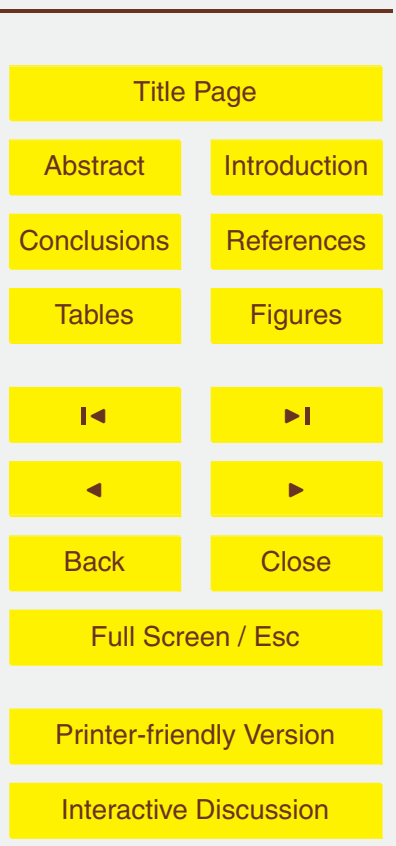


Amsterdam. Available are the water levels from the adjacent Lake IJssel during World War II, the time of the blast, the size of the initial breach, the final extent of the breach, and information about times and locations where the water arrived and how fast the water level rose in the polder. These water levels were collected by those who refused 5 to evacuate. By collecting and combining the information from all these sources to a complete dataset, we could accurately reconstruct the Wieringermeer flood.

Such reconstructions are valuable for current flood risk management. Especially in the Netherlands, it is inevitable for water authorities to be prepared for floods, because of our low elevation compared to mean sea level. All authorities practice how they will 10 act in case of a calamity and formulate evacuation plans with the intention that these will limit the damage and victims in case of a real flood. The starting point is that during this preparation all necessary knowledge is available through flood simulations with detailed elevation data. However, these models are run with default parameters based on theoretical exercises, and the results cannot be validated with data from a real situation. The 1945 Wieringermeer flood is the exception to the rule.

This paper presents the results of a retrospective analysis of this flood. We have collected available historical material, and built a combined 1-D-2-D flood propagation model that accurately reproduces the flood. First we provide a description on the history of this event. In the second part we discuss the breach growth process and inundation of the Wieringermeer polder. In the last part we discuss the reconstruction works and reconstruction costs. In each part we will try to link the flood in the Wieringermeer polder to the present flood modelling approach used in flood risk analysis.

\section{Wieringermeer polder}

The Wieringermeer polder was reclaimed from the sea between 1927 and 1930. This 25 polder was the first of four large polders reclaimed between 1927 and 1980 to enlarge the agricultural land in the Netherlands. It measures $13 \mathrm{~km}$ from west to east and $16 \mathrm{~km}$ from south to north $(20000 \mathrm{ha})$. The surface level in the Wieringermeer polder
NHESSD

1, 417-441, 2013

Reconstruction of the 1945

Wieringermeer Flood

O. A. C. Hoes et al.

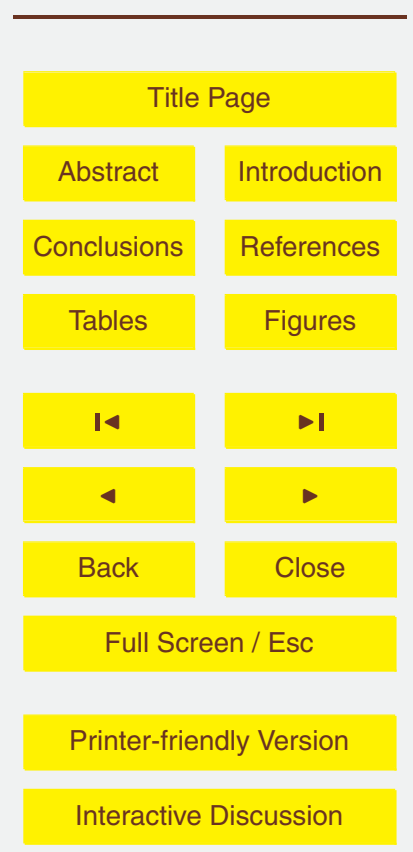


descends from $1 \mathrm{~m}$ below m.s.l. in the West towards $5 \mathrm{~m}$ below m.s.l. in the East. The interface between Pleistocene sand and Holocene clay slopes from $4 \mathrm{~m}$ below m.s.l. in the North to $13 \mathrm{~m}$ below m.s.l. in the South. The combination of these two slopes results in a thin clay layer in the Northeast, causing brackish seepage in the canals in 5 this area.

Two large pumping stations were built to discharge water: pumping station Leemans $\left(52^{\circ} 55^{\prime} 16^{\prime \prime} \mathrm{N}, 5^{\circ} 02^{\prime} 18^{\prime \prime} \mathrm{E}\right)$ with two diesel engine driven pumps of $250 \mathrm{~m}^{3} \mathrm{~min}^{-1}$ each at a head of $5.5 \mathrm{~m}$ and pumping station Lely $\left(52^{\circ} 4^{\prime} 35^{\prime \prime} \mathrm{N}, 5^{\circ} 06^{\prime} 12^{\prime \prime} \mathrm{E}\right)$ with three electric engine driven pumps of $400 \mathrm{~m}^{3} \mathrm{~min}^{-1}$ each at a head of $6 \mathrm{~m}$.

10 The construction of the Wieringermeer was organized by the national government, who created an ultramodern polder with - for those days - large parcels of 20 ha and an extensive network of navigable canals and sluices to transport agricultural products by ship. Three villages were built: Wieringerwerf, Middenmeer and Slootdorp, of which the village Wieringerwerf (located in the centre of the polder) was planned to become the main village. In retrospect, the three villages were built too close to each other and too far away from the so-called old land. Next, Middenmeer was built before Wieringerwerf and was also closer to the old land then Wieringerwerf. As a result Middenmeer developed naturally as a main village next to Wieringerwerf (Cock and Willemse, 1955; Terpstra and Vogt, 1980). The first young pioneers who colonized the polder came from all over the Netherlands and were aware that they had to build a new community on an unique piece of land. This can be illustrated by the existence of more than 30 different societies and clubs within three months after the first settlers arrived, providing the necessary contacts for a respectable social life (Kamp, 1937). The core binding factor was however the absence of a municipality board. In 1930 the new polder area was divided in five sections and added to the adjacent existing municipalities on the surrounding old land. However, the differences between the old and new land were so large, that it brought the Wieringermeer residents unintentionally closer to each other. This changed in 1938 by the founding of the public institution of the Wieringermeer. On 1 July in 1941 this became the municipality of the Wieringermeer.

\section{NHESSD}

$1,417-441,2013$

Reconstruction of the 1945

Wieringermeer Flood

O. A. C. Hoes et al.

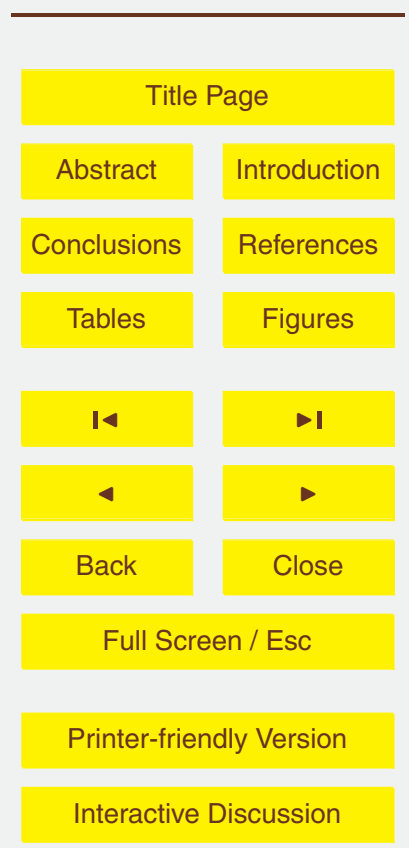




\section{Preparatory activities}

The inundation of the Wieringermeer in 1945 did not occur unexpectedly, but why the Germans finally decided to go ahead is unknown. The first reports from inundated polder areas as a German war strategy in the Netherlands date from February 1944. 5 Between February and September the German army inundated around 120000 ha by blocking the discharge of excess water (see also Fig. 2). A telegram from the resistance on the 16 February 1944 to the Dutch government in exile in England stated that the German army wanted to raise the water level of Lake IJssel (Waalewijn, 1985).

A high water level was required to have a necessary buffer of water for inundations.

Starting from the 27 February the maintained water level became $-0.13 \mathrm{~m}$ m.s.l. The pre-war target level was $-0.2 \mathrm{~m}$ m.s.l. in the summer and $-0.4 \mathrm{~m}$ m.s.l. in the winter. Starting from October the water level in Lake IJssel was further raised till it reached $+0.36 \mathrm{~m}$ m.s.l. on the 18 November 1944 (Fig. 3).

At the end of February 1945 the activities at the Wieringermeer dike commenced $15\left(52^{\circ} 5^{\prime} 26^{\prime \prime} \mathrm{N}, 5^{\circ} 0^{\prime} 32^{\prime \prime} \mathrm{E}\right)$. The plan was to dig ten holes of $7 \mathrm{~m}$ deep and $1.5 \mathrm{~m}$ in diameter at two locations; four holes in the inner slope, two at the crest, and four in the outer slope. Each hole contained a masonry lining to increase the impact of the blast. At the 14 April, all 20 holes were dug, but the brickwork was not finished yet. Nevertheless, on the 15 and 16 April, $1000 \mathrm{~kg}$ of explosives was lowered in each hole. All the explosives were connected by electrical wire and connected to one master clock (Romburgh, 1987).

\section{Tuesday the 17 April 1945}

At four o'clock in the morning the Mayor of the Wieringermeer was informed by the Germans that they would blow up the dike around noon. There was an evacuation plan for such situations, but that did not work out as foreseen. In the plan the polder was divided into five sections with each a commanding officer. These five officers were

\section{NHESSD}

$1,417-441,2013$

Reconstruction of the 1945

Wieringermeer Flood

O. A. C. Hoes et al.

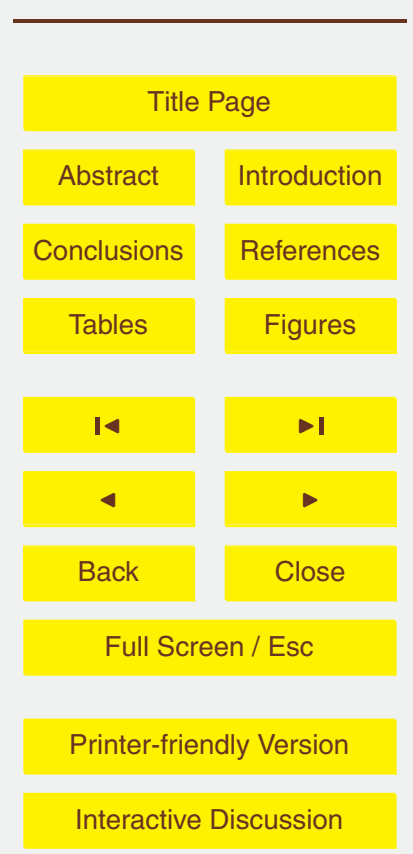


assisted by 68 group leaders. Every resident belonged to a group of around 100 people and a fixed meeting point was assigned to every group (Bijdorp, 2007).

All people were asked to show up at the assigned meeting point at $10 \mathrm{a} . \mathrm{m}$. where they would be informed about their group's destination. The destinations were not 5 known in advance to avoid that people would switch to groups heading towards more popular destinations. In reality no one showed up at their meeting point but left the area individually. The farmers had the advantage of owning horse carts, and took some of their belongings with them. The villagers in the middle of the polder without a cart, had to flee almost $12 \mathrm{~km}$ on foot to reach higher ground. Only a limited number of people - stayed at home to prevent plundering.

The blast was at 12.15 p.m. and was heard up to $25 \mathrm{~km}$ away. Farmers who wanted to approach the location were stopped by the German army, but from a distance they saw that there was some water seeping through one shallow groove, and that the other groove failed to cause any flow. The German army would have shovelled both grooves wider and deeper to further initiate the water flow (Pladdet-Dees, 1946).

The villagers, who stayed at home during the time that the polder was flooded, left the area several days later by boat after the waves caused by several spring storms started to destruct the first houses. None of the 7000 official residents and 2000 refugees in hiding drowned during the flood, and also the majority of the cattle survived. During the weeks that followed only the corpses of 1 horse, 26 cows and 2 pigs were collected from the water (Directie van de Wieringermeer, 1955).

\section{Breach growth}

Research on breach growth has occasionally been conducted during the last decades, especially by Japanese, American, and Dutch researchers. The research in the US focuses on so called fuse plugs. In the US situation, sand dams fuse plugs are used in spillways of reservoirs to prevent any uncontrolled overflow. In the Netherlands research started around 1990 with breach experiments of sand dikes (TAW, 1994). Later,

\section{NHESSD}

$1,417-441,2013$

Reconstruction of the 1945

Wieringermeer Flood

O. A. C. Hoes et al.

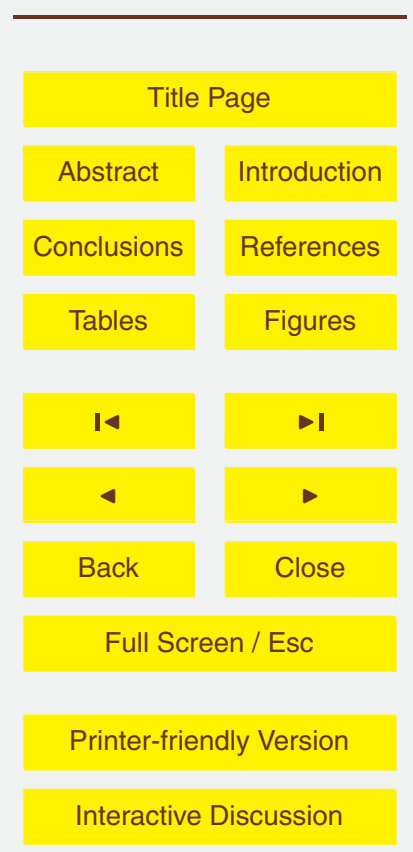


this research extended towards cohesive soils, like clay dikes (Zhu, 2006). In general dike breach development can be divided in 5 phases (Costa, 1985; Visser, 1998; Fujisawa, 2009; Chang, 2010; Vorogushyn, 2011). Phase wise details are provided hereby:

\subsection{Gully erosion at the inner slope}

5 With just a small amount of water seeping through, the flow velocity is rather slow through the groove (somewhere between 0 and $1 \mathrm{~ms}^{-1}$ ), but increases over the inner slope of the dike. At this stage the inner slope erodes causing the slope of the gully to become steeper until a maximum slope. This corresponds with Fig. 4a to Fig. 4b.

\subsection{Head cut migration}

10 In this phase the gully develops backward - in our case in the direction of Lake IJssel. After a while the gully reached the outer slope of the dike and nothing was left from the original crest. Up until this moment, the groove was wider at the Wieringermeer side of the dike compared to the Lake IJssel side of the dike. In this phase the first scratches of what would become two deep scour holes appeared, as the water had to change its direction after it hit the polder floor. This corresponds with Fig. $4 \mathrm{~b}$ via Fig. 4c to Fig. 4 d.

\subsection{Vertical deepening of the breach}

The last remaining portion of the original dike was a triangular slice at the outer slope (lakeside). When this slice started to decrease, the flow velocity increased. At the end, the old dike disappeared and from now on the breach became wider at the lakeside compared to the polder side of the breach. The flow velocity depends on the difference in water level over the breach. In this case, it was $H=3.5 \mathrm{~m}$. Therefore, the velocity $v$ increased up to 3 to $4 \mathrm{~ms}^{-1}$. This corresponds with Fig. $4 \mathrm{~d}$ to Fig. $4 \mathrm{e}$.

\section{NHESSD}

$1,417-441,2013$

Reconstruction of the 1945

Wieringermeer Flood

O. A. C. Hoes et al.

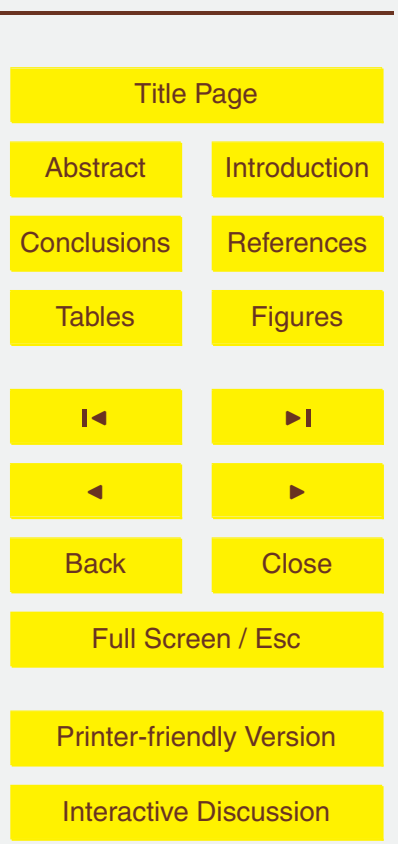




\subsection{Widening of the breach}

The breach width started to grow seriously as the increased velocity eroded submerged sidewalls of the breach. That caused the sand of the sidewalls to slide into the raging water and being flushed out of the breach. In the prior phases, the side walls did also

5 slide into the water, but at that time there was more time needed to transport/flush the sand away as the velocity was lower. This corresponds with Fig. 4e to Fig. $4 \mathrm{f}$.

\subsection{Transition super to sub critical flow}

After a while, the water level in the Wieringermeer polder started to rise seriously, thereby decreasing the speed with which the water flowed into the polder. That reduced the turbulence and the growth of the scour holes. After the flow of water became subcritical, the breach was only growing slowly. This growth stopped when the shear stresses were low enough for the material of the dike side walls and bottom surface to stay in place. Eventually, the velocity $v$ decreased slowly to $0 \mathrm{~ms}^{-1}$, when the water level in the Wieringermeer Polder approached the water level at Lake IJssel. This 15 corresponds with Fig. $4 \mathrm{f}$ to Fig. $4 \mathrm{~g}$.

The final result was 692 million $\mathrm{m}^{3}$ of water in the Wieringermeer and two large scour holes, which are still present today. The two scour holes are different in size, though the starting point for both breaches was almost the same: 10 wells with $1000 \mathrm{~kg}$ of explosives that exploded at the same time. At present, the southern scour hole is area. Apparently, small differences in the beginning in combination with the non-linear erosion processes are sufficient to result in a totally different end situation. It is because of this unpredictability of the breach growth process, that flood simulations must be judged with care.

\section{NHESSD}

1, 417-441, 2013

Reconstruction of the 1945

Wieringermeer Flood

O. A. C. Hoes et al.

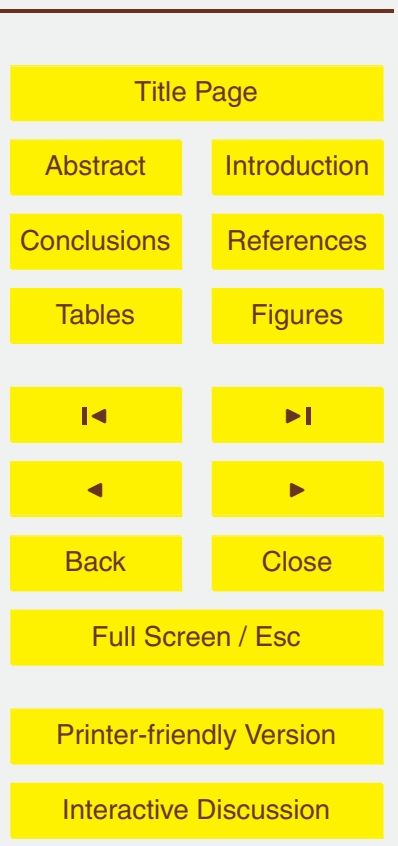




\section{Inundation pattern}

Although the Netherlands are thought of being very flat, there are height differences in all polders. As mentioned, the Wieringermeer polder surface slopes from $-1 \mathrm{~m}$ m.s.l. in the west to $-5 \mathrm{~m} \mathrm{~m}$.s.l. in the east over a distance of about $12 \mathrm{~km}$. This sloped sur-

5 face has braided through a pattern of canals and ditches, causing flood water flowing differently in each direction over the surface, although water tends to flow to the lowest point faster and spreads from there on further upward. The lowest points, however, are the ditches and canals. As a result, these canals fill up in the first hours, with the water being redistributed as shallow water waves $(v=\sqrt{(g \cdot d)}$ with $g$ gravitational conwater flow over the surface. As soon as the canals are filled, water will rise out of them into the lowest fields. As a result, in the Wieringermeer polder, flood water blocked the evacuation routes from the three villages towards the higher grounds in the Southeast (Bijdorp, 2007).

15 The resulting inundation pattern from Fig. 5 was simulated with Sobek 1-D-2-D software (Delft Hydraulics, 2000). The basis for our model was a $25 \mathrm{~m}$ resolution digital elevation map (DEM). This DEM was collected in 1997 with a laser altimeter mounted on a helicopter. Because of the course pixel resolution, not all canals and ditches are featured in the DEM. They were added to the schematisation as 1-D line elements with their appropriate profile and elevation and then were connected to the DEM.

The model was calibrated with historical data of times and locations of water arrival and water level rise in the polder collected by those who refused to evacuate. Among the data used are the measured data of the sacristan from the village of Wieringerwerf. The sacristan saw his yard becoming inundated around 0.30 a.m. on 18 April 1945.

This was $12 \mathrm{~h}$ and $15 \mathrm{~min}$ after the blast. At $3 \mathrm{a} . \mathrm{m}$. the water entered his house, and at 4 a.m., he measured $21 \mathrm{~cm}$. At 5 a.m. there was $40 \mathrm{~cm}$ and at 8 a.m. already $57 \mathrm{~cm}$. At noon it was $85 \mathrm{~cm}$ and the next evening at midnight he measured $177 \mathrm{~cm}$ (Cock and Willemse, 1955). Others reported that it took until early in the morning on Wednesday
NHESSD

$1,417-441,2013$

Reconstruction of the 1945

Wieringermeer Flood

O. A. C. Hoes et al.

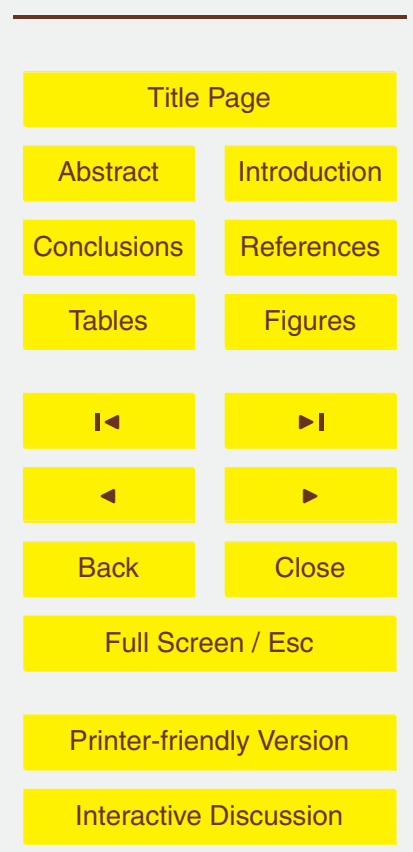


before the water entered the streets of the village of Middenmeer. At 5.30 a.m., the water entered the Flevo-road (Keppel et al., 1995). Around 11 a.m. the water level in Middenmeer was around half a meter (Bijdorp, 2007).

In our case, this information could be combined with the final dimensions of the 5 breach (which is known); the only effective calibration parameter left was the time needed for the breach to reach its final depth. The transition from Fig. $4 \mathrm{a}$ to Fig. $4 \mathrm{e}$ must have taken place after $12 \mathrm{~h}$ in order to have a water level rise that fit the data from the sacristan in Wieringerwerf (Fig. 6). This duration of $12 \mathrm{~h}$ corresponds with the extensive report from Rijkswaterstaat (1961) that suggests that the width of a dike, 10 and the presence of a boulder clay dam in the dike with a stone revetment - as in the Wieringermeer - can seriously slow down the breach growth process. For modern flood simulations water authorities in the Netherlands assume smaller default periods for breach growth. In 2010 the provinces in the Netherlands combined all their 3000 flood simulations in one database. $88 \%$ of those were run with a "time to reach maxi-

\section{Reconstruction works}

Immediately after the liberation on the 5 May 1945, the Public Works department worked on a plan to close the dike. They decided to build a $940 \mathrm{~m}$ long new dike in Lake IJssel around the deep scour holes. This solution was preferred over filling the scour holes, as this would have required much more sand and also the subsidence would be uncertain. The location and shape of the scour holes made that a new dike in the polder itself would have required more sand and boulder clay. The first sand was dumped on the 21 June 1945; on the 5 August the dike was closed.

On the 9 August pumping could start to discharge around 616 million $\mathrm{m}^{3}$ of water. 25 This is somewhat less than the before mentioned 692 million $\mathrm{m}^{3}$ that inundated the polder, as the water level of Lake IJssel had already been lowered to $-0.4 \mathrm{~m}$ m.s.l. (Fig. 8) to minimize the water volume in the Wieringermeer. In the subsequent months,

NHESSD

1, 417-441, 2013

Reconstruction of the 1945

Wieringermeer Flood

O. A. C. Hoes et al.

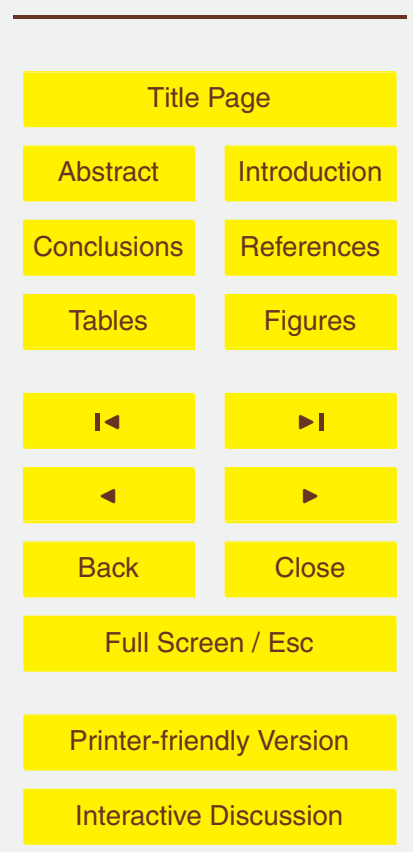


the two pumping stations Leemans and Lely discharged 469 million $\mathrm{m}^{3}$, but not without problems. The suction side of the southern pumping station Lely was frequently blocked by floating debris. This was solved by deploying German torpedo-nets in front of the suction side of the pumping station. Next, 55 million $\mathrm{m}^{3}$ water was discharged under 5 free flow through a sluice towards a nearby polder. 101 million $\mathrm{m}^{3}$ was discharged with 11 emergency pumps. At the 11 December - 125 days after the first pump started the water in the polder was back at $-5 \mathrm{~m}$ m.s.l.

With the flood water gone and the surface of the polder finally dry, the damage became visible. The Wieringermeer showed an unpleasant view of ruins of what had been churches, farms, and houses. Without exception all buildings were at least damaged: in Wieringerwerf 155 houses out of 165 were destroyed, and in Slootdorp 120 houses out of 150 and in Middenmeer 176 houses out of 221 were destroyed. Furthermore, from the 513 farmhouses $90 \%$ was destroyed. This devastation was mainly because the buildings could not resist the beating of the waves during the storms in the spring and summer of 1945 . Without these storms the damage would have been much less. For today's simulations this is an interesting aspect, as wave impact is never taken into account in a priori damage calculations. Factors mainly included are inundation depth, and sometimes flow velocity or duration (Merz et al., 2010).

The reconstruction of the polder cost $\$ 10$ million (see Table 1) and took $5 \mathrm{yr}$. Nevertheless, the farmers started to cultivate their land directly in the spring of 1946 with less intensive crops. Doing this, they were able to harvest a nearly complete yield in 1946 (Dienst Wederopbouw Wieringermeer, 1948).

\section{Discussion and conclusions}

Interest in preventing floods has increased in recent years due to extraordinary floods, e.g. the 2004 Tsunami, Hurricane Katrina in 2005, the floods in Pakistan in 2010 and 2011, Japan's Tsunami in 2011, and the necessity to prepare for the impacts of climate change. Research institutes, water authorities, and consultancy firms in many

\section{NHESSD}

$1,417-441,2013$

Reconstruction of the 1945

Wieringermeer Flood

O. A. C. Hoes et al.

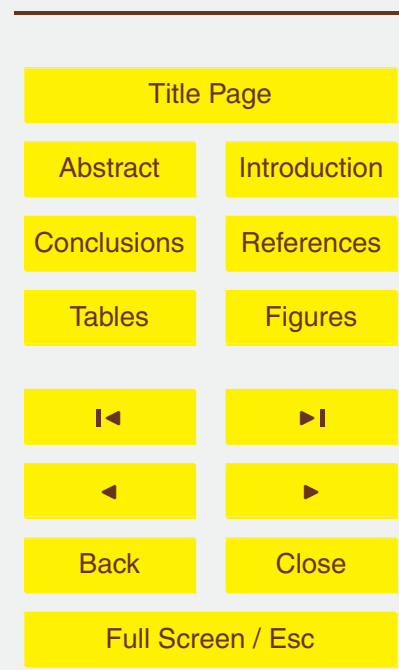

Printer-friendly Version

Interactive Discussion 
countries conduct flood studies, improve emergency plans and develop measures to arrange a more robust environment. Within this process the focus is on possible future scenarios, but every now and then it is good to look back to past events to learn lessons. Several aspects from the inundation of the Wieringermeer are now $-65 \mathrm{yr}$ 5 later - still relevant.

A polder inundates by a combination of $(A)$ water that is rapidly redistributed through the existing drainage network of canals and ditches and $(B)$ water that flows radially, but slower over the fields starting from the breach location. The water redistributed by the network might inundate the lowest fields at quite some distance from the breach before 10 overland flow can reach the same places. Furthermore, this water might unexpectedly block the evacuation routes.

Only near the breach, the flow velocities are high enough to initiate structural damage to buildings. The actual damage to buildings is likely to occur because of the wave impact of storms during the period that a polder is inundated. This damage is never explicitly considered in the flood damage estimation models used at present.

Two aspects determine the velocity with which a polder floods. First of all the upstream water level and water volume. In case of Lake IJssel, the total surface of $2770 \mathrm{~km}^{2}$ in 1945 is nowadays reduced by the construction of the Flevopolder and the Houtribdijk in the sixties and seventies to $1100 \mathrm{~km}^{2}$. The same disaster nowadays will result in a smaller inundation depth. If one considers to compartmentalise a polder, one should also consider to compartmentalise the upstream water body. The second aspect is breach growth, which determines the water level rise. In our simulation of the Wieringermeer flood the final breach size was used as input. Next, the breach growth process was selected such that the water level rise correspond to historical measurements. However, for many simulations the final measurements are not known in advance, and are the choice of the modeller. The predictive value from these simulations must be cautiously interpreted. Smaller or larger breaches are just as realistic, because of the non-linearities of the erosion processes.
NHESSD

$1,417-441,2013$

Reconstruction of the 1945

Wieringermeer Flood

O. A. C. Hoes et al.

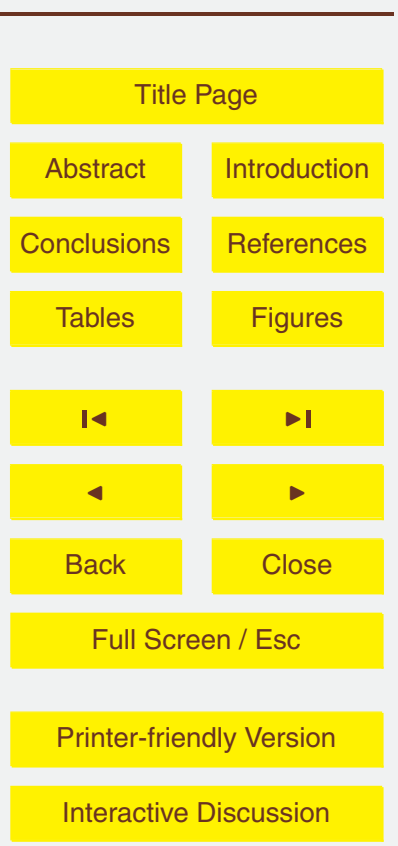


The present state-of-the-art in flood risk management is applying models which need to be validated with real data to avoid erroneous conclusions. This case study shows that historical floods provide valuable data for the validation of models and reveals lessons that are applicable in current day flood risk management.

5 Supplementary material related to this article is available online at: http://www.nat-hazards-earth-syst-sci-discuss.net/1/417/2013/ nhessd-1-417-2013-supplement.zip.

\section{References}

Apel, H., Thieken, A. H., Merz, B., and Blöschl, G.: Flood risk assessment and associated uncertainty, Nat. Hazards Earth Syst. Sci., 4, 295-308, doi:10.5194/nhess-4-295-2004, 2004.

Apel, H., Thieken, A. H., Merz, B., and Blöschl, G.: A probabilistic modelling system for assessing flood risks, Nat. Hazards, 38, 79-100, doi:10.1007/s11069-005-8603-7, 2006.

Apel, H., Aronica, G. T., Kreibich, H., and Thieken, A. H.: Flood risk analyses - how detailed do we need to be?, Nat. Hazards, 49, 79-98, doi:10.1007/s11069-008-9277-8, 2009.

15 Baart, F., Bakker, M. A. J., van Dongeren, A., den Heijer, C., van Heteren, S., Smit, M. W. J., van Koningsveld, M., and Pool, A.: Using 18th century storm-surge data from the Dutch Coast to improve the confidence in flood-risk estimates, Nat. Hazards Earth Syst. Sci., 11, 2791-2801, doi:10.5194/nhess-11-2791-2011, 2011.

Bijdorp, B. A.: 1940-1945, Wieringermeer in de Bezettingsjaren, Historisch Genootschap Wieringermeer, Middenmeer, 2007.

Bouwer, L. M., Bubeck, P., Wagtendonk, A. J., and Aerts, J. C. J. H.: Inundation scenarios for flood damage evaluation in polder areas, Nat. Hazards Earth Syst. Sci., 9, 1995-2007, doi:10.5194/nhess-9-1995-2009, 2009.

Chang, D. S. and Zhang, L. M.: Simulation of the erosion process of landslide dams due to overtopping considering variations in soil erodibility along depth, Nat. Hazard Earth Sys. Sci., 10, 933-946, doi:10.5194/nhess-10-933-2010, 2010.

Costa, J. E.: Floods from dam failures, Rep. Nr. 85-560, US Geological Survey, Denver, 59 pp., 1985.

\section{NHESSD}

1, 417-441, 2013

Reconstruction of the 1945

Wieringermeer Flood

O. A. C. Hoes et al.

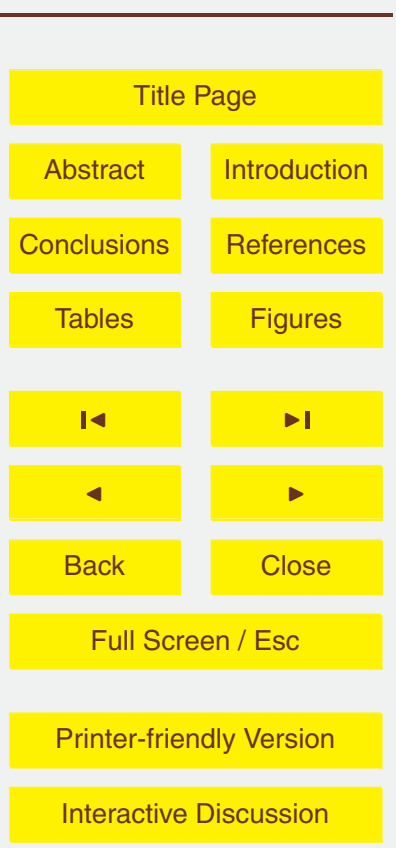


de Cock, E. and Willemse, W. J. Z.: De Inundatie van de Wieringermeer in 1945, een rapport over de evacuatie en de terugkeer van de Wieringermeerbevolking, N. Samson, Alphen a/d Rijn, 1955.

Dienst Wederopbouw Wieringermeer: Verslag van de werkzaamheden over de periode 19451946, Dienst Wederopbouw Wieringermeer, Den Haag, 1948.

Directie van de Wieringermeer: Wording en opbouw van de Wieringermeer, geschiedenis van de ontginning en kolonisatie van de eerste IJsselmeerpolder, Veenman, Wageningen, 1955.

Fujisawa, K., Kobayashi, A., and Aoyama, S.: Theoretical description of embankment erosion owing to overflow, Geotechnique, 59, 661-671, doi:10.1680/geot.7.00035, 2009.

10 Gottschalk, M. K. E.: Stormvloeden en Rivieroverstromingen in Nederland, van Gorcum, Assen, 1977.

Jelgersma, S., Stive, M., and van der Valk, L.: Holocene storm surge signatures in the coastal dunes of the Western Netherlands, Mar. Geol., 125, 95-110, 1995.

Jong, L. de.: Koninkrijk der Nederlanden in de Tweede Wereldoorlog, deel Xb: 1441, Martinus Nijhoff, Leiden, 1982.

Jonkman, S. N., Bockarjova, M., Kok, M., and Bernardine, P.: Integrated hydrodynamic and economic modelling of flood damage in the Netherlands, Ecol. Econ., 66, 77-90, 2008.

Kamp, A. F.: Zuiderzee-land, verleden en toekomst van de Zuiderzee, Querido, Amsterdam, 1937.

20 Keppel, C., Brugman, N., and Maris-Eriks, W.: 17 April 1945: Het koolzaad bloeide zo mooi goudgeel, Historisch Genootschap Wieringermeer, Middenmeer, 1995.

Kreibich, H., Piroth, K., Seifert, I., Maiwald, H., Kunert, U., Schwarz, J., Merz, B., and Thieken, A. H.: Is flow velocity a significant parameter in flood damage modelling?, Nat. Hazards Earth Syst. Sci., 9, 1679-1692, doi:10.5194/nhess-9-1679-2009, 2009.

Lumbroso, D. M. and Vinet, F.: A comparison of the causes, effects and aftermaths of the coastal flooding of England in 1953 and France in 2010, Nat. Hazards Earth Syst. Sci., 11, 2321-2333, doi:10.5194/nhess-11-2321-2011, 2011.

Manen, S. E. van and Brinkhuis, M.: Quantitative flood risk assessment for polders, Reliab. Eng. Syst. Safe., 90, 229-237, 2005.

30 Merz, B., Kreibich, H., Schwarze, R., and Thieken, A.: Review article "Assessment of economic flood damage", Nat. Hazards Earth Syst. Sci., 10, 1697-1724, doi:10.5194/nhess-10-16972010, 2010.

Pladdet-Dees, P.: De Terp als reddingsboei, s.n., 1946.

\section{NHESSD}

1, 417-441, 2013

Reconstruction of the 1945

Wieringermeer Flood

O. A. C. Hoes et al.

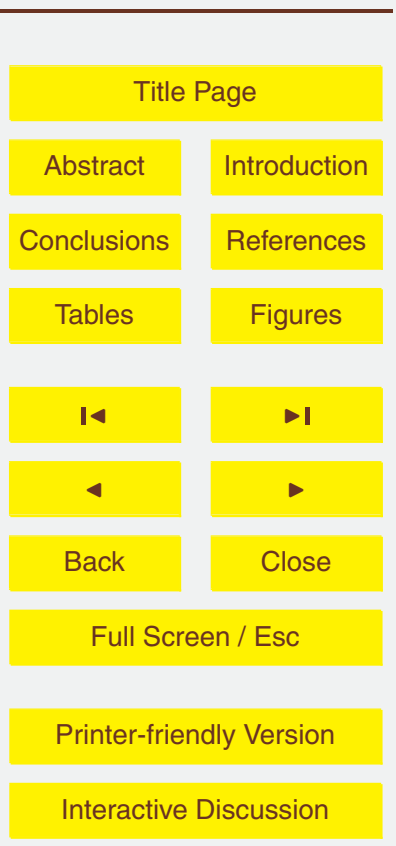


Rijkswaterstaat: Verslag over de Stormvloed 1953, Staatsdrukkerij, 's-Gravenhage, 1961.

Romburgh, C. P. P.: De inundatie van de Wieringermeerpolder in april 1945, Stichting voor het bevolkingsonderzoek in de drooggelegde Zuiderzeepolders, Amsterdam, 1987.

Tariq, M. A. U. and van de Giesen, N. C.: Floods and flood management in Pakistan, Phys. Chem. Earth, 47, 11-20, doi:10.1016/j.pce.2011.08.014, 2012.

TAW: Het Zwin, successen en lessen bresgroeiexperimenten, Technische Adviescommissie voor de Waterkeringen, Delft, 1994.

Terpstra P. and Vogt, P.: 50 jaar Wieringermeer, van Seijen, Leeuwarden, 1980.

Visser, P. J.: Breach growth in sand dikes, Ph.D. thesis, Delft University of Technology, Delft, 1998.

Vorogushyn, S., Apel, H., and Merz, B.: The impact of the uncertainty of dike breach development time on flood hazard, Phys. Chem. Earth, 36, 319-323, 2011.

Waalewijn, A.: Waterstaat in Londen 1940-1945, Ministerie van Verkeer en Waterstaat, Den Haag, 1985.

WL-Delft Hydraulics: Delft 1D-2D, Manual Sobek overland flow module, WL-Delft Hydraulics, Delft, 2000.

Zhu, Y.: Breach growth in clay dikes, Ph.D. thesis, Delft University of Technology, Delft, 2006.

\section{NHESSD}

1, 417-441, 2013

\section{Reconstruction of the 1945}

\section{Wieringermeer Flood}

O. A. C. Hoes et al.

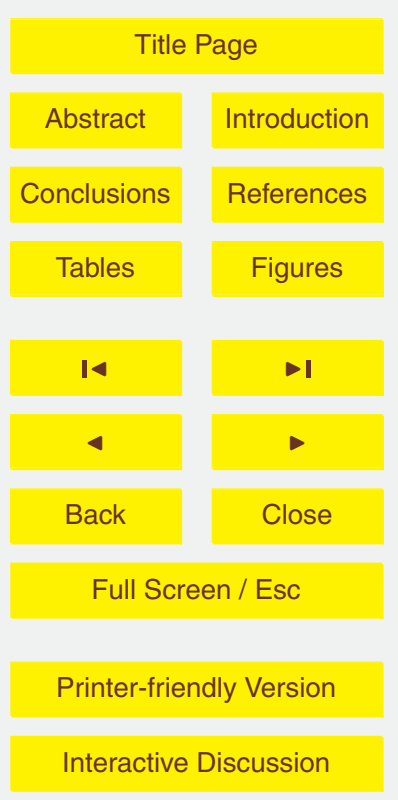




\section{NHESSD}

$1,417-441,2013$

Table 1. Reconstruction cost (Terpstra and Vogt, 1980) ${ }^{\mathrm{a}}$.

\begin{tabular}{lr}
\hline Item & Damage \\
\hline Rebuilding farm houses & $\$ 4775000 .-$ \\
Communal cost, labour quarters etc & $\$ 2590000 .-$ \\
Restoration of canals and drains & $\$ 675000 .-$ \\
Removing debris & $\$ 555000 .-$ \\
Rebuilding dikes & $\$ 415000 .-$ \\
Recovery of electricity, water services & $\$ 400000 .-$ \\
Rebuilding schools & $\$ 230000 .-$ \\
Roads, bridges and office buildings & $\$ 185000 .-$ \\
Planting trees & $\$ 165000 .-$ \\
Emptying the polder & $\$ 100000 .-$ \\
\hline Total & $\$ 10000000 .-$ \\
\hline
\end{tabular}

${ }^{a}$ The actual damage was higher as lost household contents, farm equipment, cattle, the harvest of 1945 and cost to temporarily accommodate the residents is not part of the reconstruction cost.

\section{Reconstruction of the 1945 \\ Wieringermeer Flood \\ O. A. C. Hoes et al.

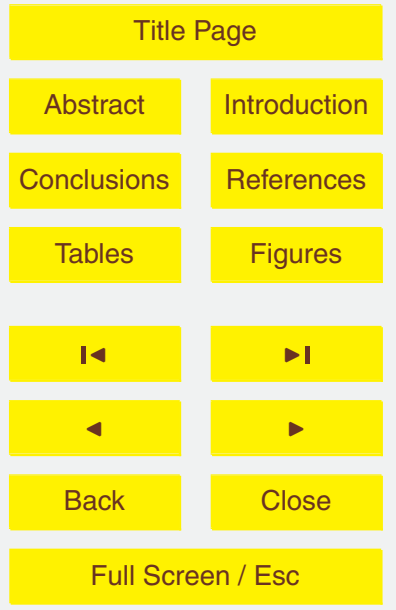

Printer-friendly Version

Interactive Discussion 


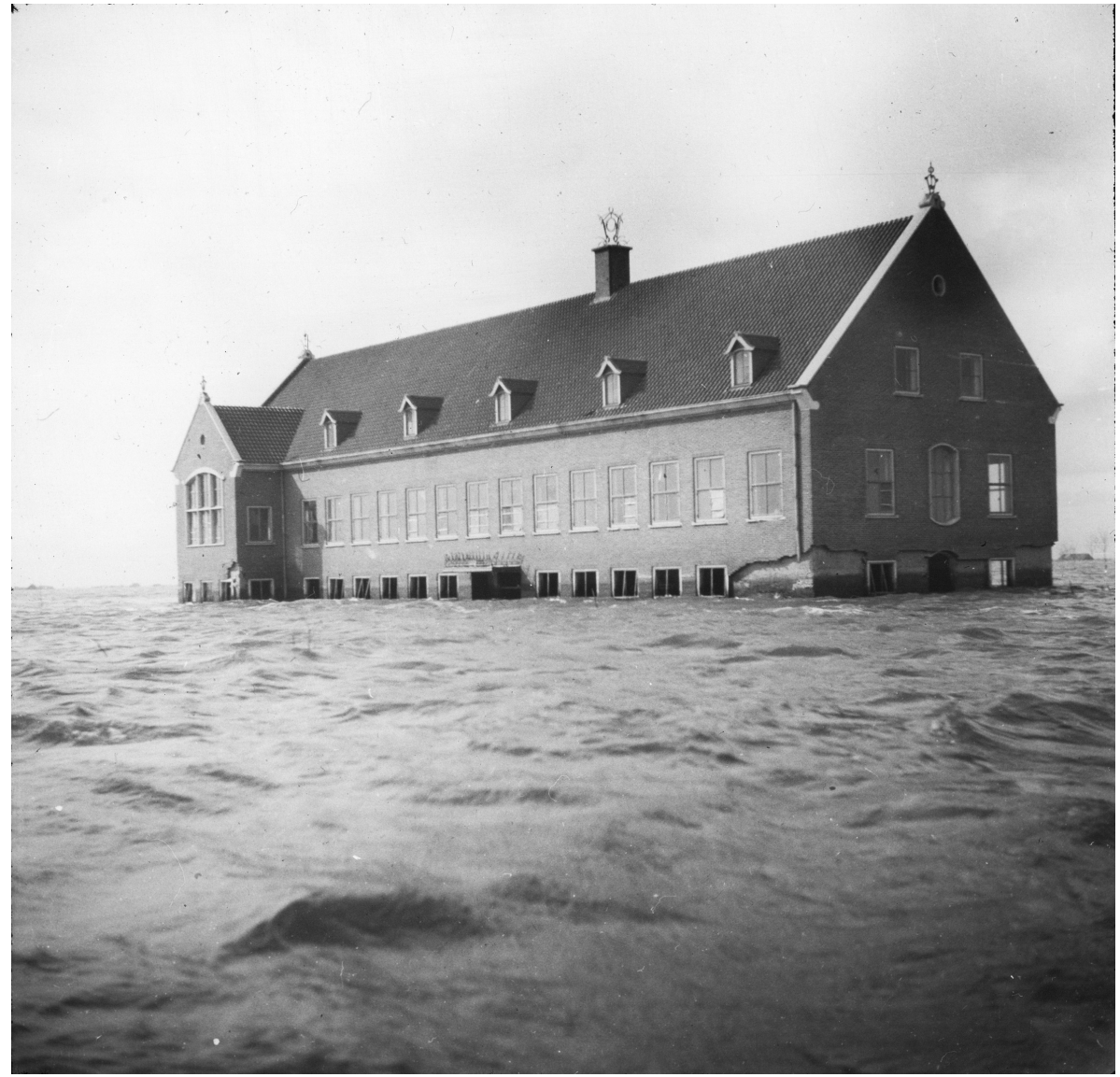

Fig. 1. Office building in Wieringerwerf during the inundation. Around 30 people sheltered 3 weeks in this building until the capitulation on 5 May 1945.

\section{NHESSD}

$1,417-441,2013$

\section{Reconstruction of the 1945 \\ Wieringermeer Flood}

O. A. C. Hoes et al.

Title Page

\begin{tabular}{|c|c|}
\hline Abstract & Introduction \\
\hline Conclusions & References \\
\hline Tables & Figures \\
\hline I4 & \\
\hline Back & \\
\hline Full Screen / Esc \\
\hline
\end{tabular}

Printer-friendly Version

Interactive Discussion 


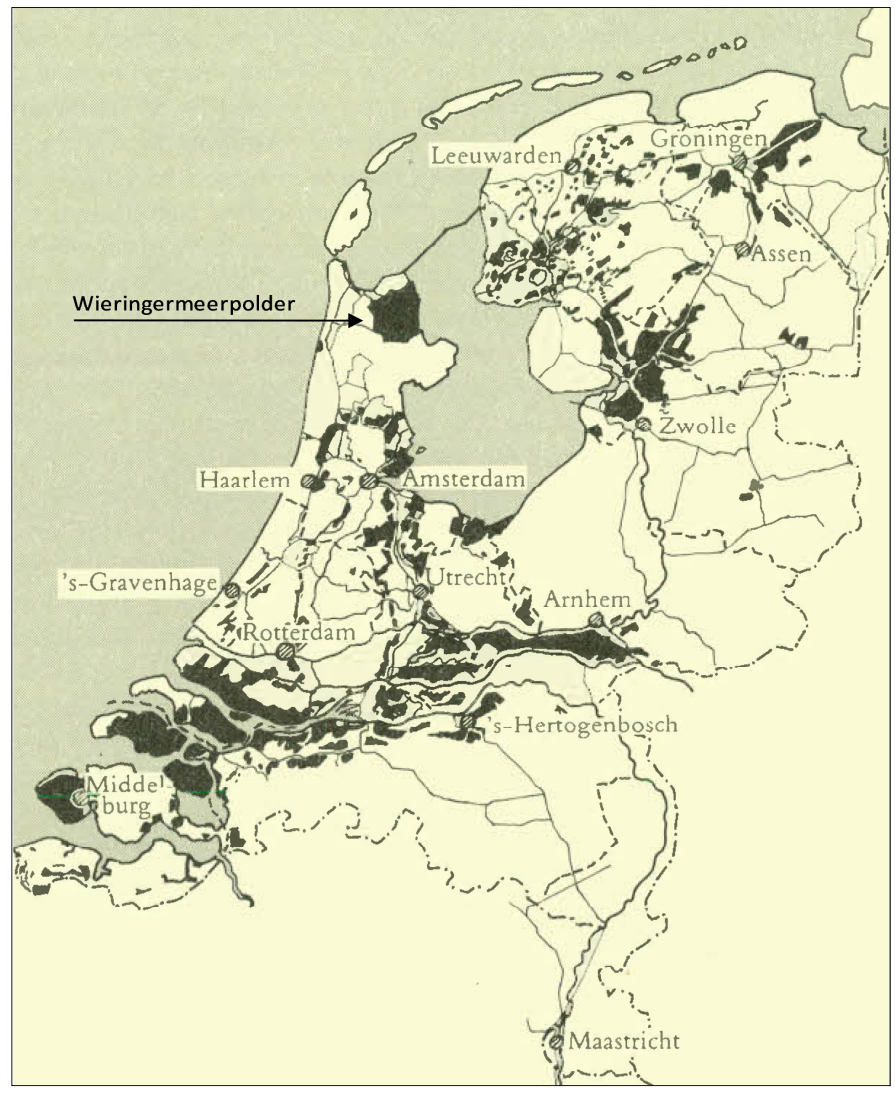

\section{NHESSD}

$1,417-441,2013$

\section{Reconstruction of the 1945 \\ Wieringermeer Flood}

O. A. C. Hoes et al.

\begin{tabular}{|c|c|}
\hline \multicolumn{2}{|c|}{ Title Page } \\
\hline Abstract & Introduction \\
\hline Conclusions & References \\
\hline Tables & Figures \\
\hline I4 \\
\hline Back \\
\hline Full Screen / Esc \\
\hline Printer-friendly Version \\
\hline Interactive Discussion
\end{tabular}

Fig. 2. Around 220000 ha were inundated in May 1945 (de Jong, 1982). 


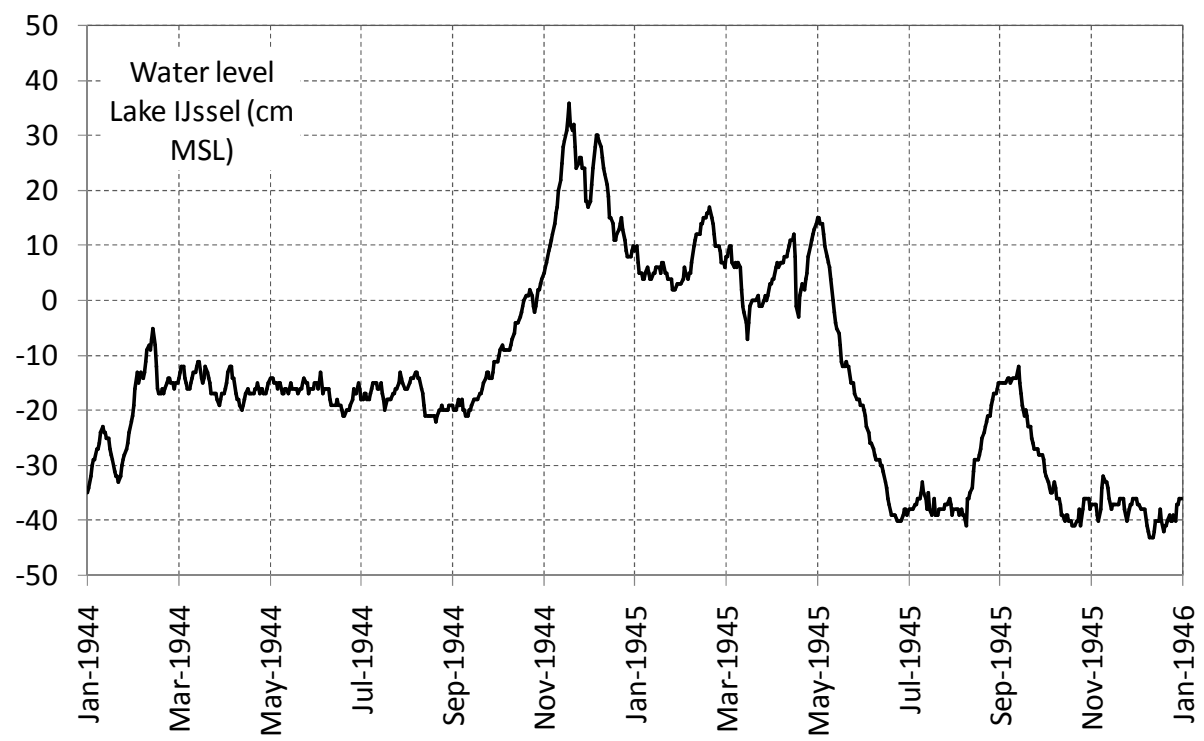

Fig. 3. Water level at Lake IJssel during 1944 and 1945. The usually maintained water levels are $-40 \mathrm{~cm}$ m.s.l. in winter and $-20 \mathrm{~cm}$ m.s.l. in summer.

\section{NHESSD}

$1,417-441,2013$

\section{Reconstruction of the 1945 \\ Wieringermeer Flood}

O. A. C. Hoes et al.

\section{Title Page}

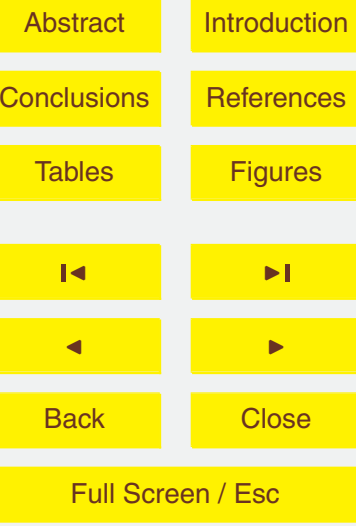

Printer-friendly Version

Interactive Discussion 


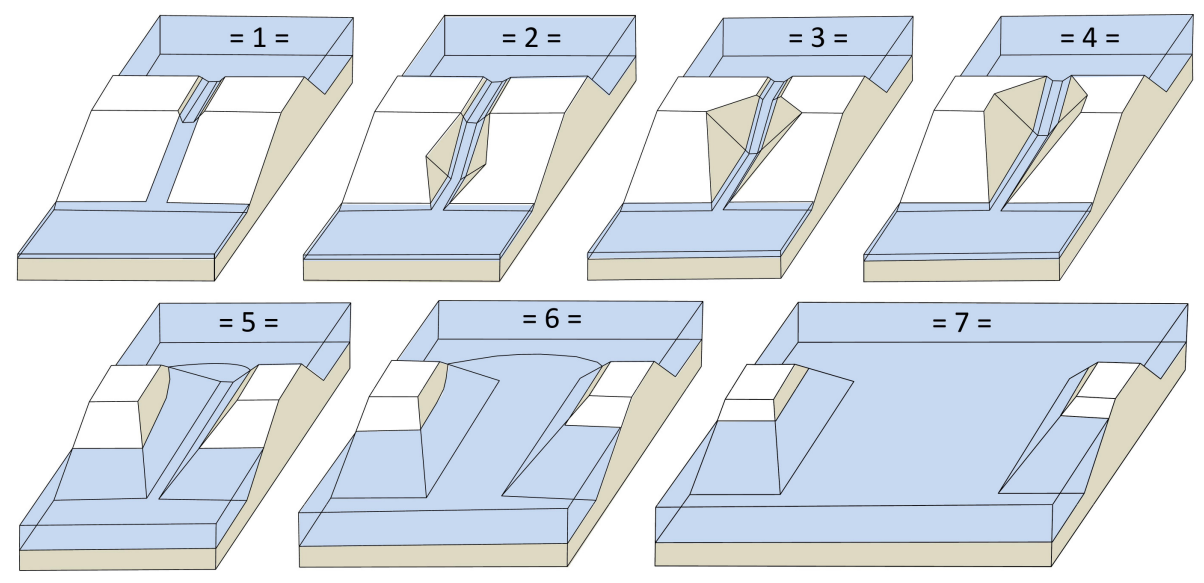

Fig. 4. Dike breach development phases (after Visser, 1998).

\section{NHESSD}

1, 417-441, 2013

\section{Reconstruction of the 1945 \\ Wieringermeer Flood}

O. A. C. Hoes et al.

\begin{tabular}{|c|c|}
\hline \multicolumn{2}{|c|}{ Title Page } \\
\hline Abstract & Introduction \\
\hline Conclusions & References \\
\hline Tables & Figures \\
\hline I4 & \\
\hline & \\
\hline Back & Close \\
\hline Full Screen / Esc \\
\hline Printer-friendly Version \\
\hline Interactive Discussion
\end{tabular}



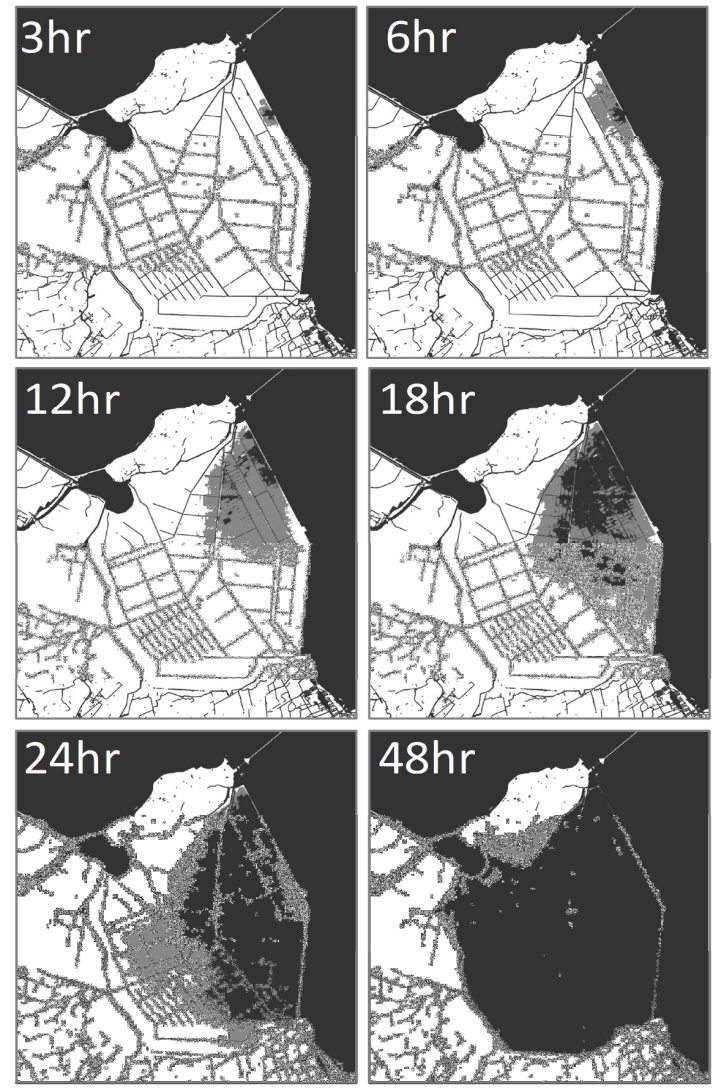

Fig. 5. Simulated inundation pattern after the blast. The filling took around $48 \mathrm{~h}$ due to the large size of the polder.

\section{NHESSD}

$1,417-441,2013$

\section{Reconstruction of the 1945}

Wieringermeer Flood

O. A. C. Hoes et al.

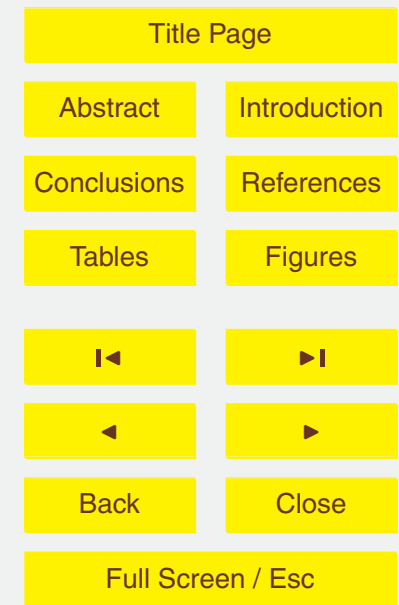

Printer-friendly Version

Interactive Discussion 


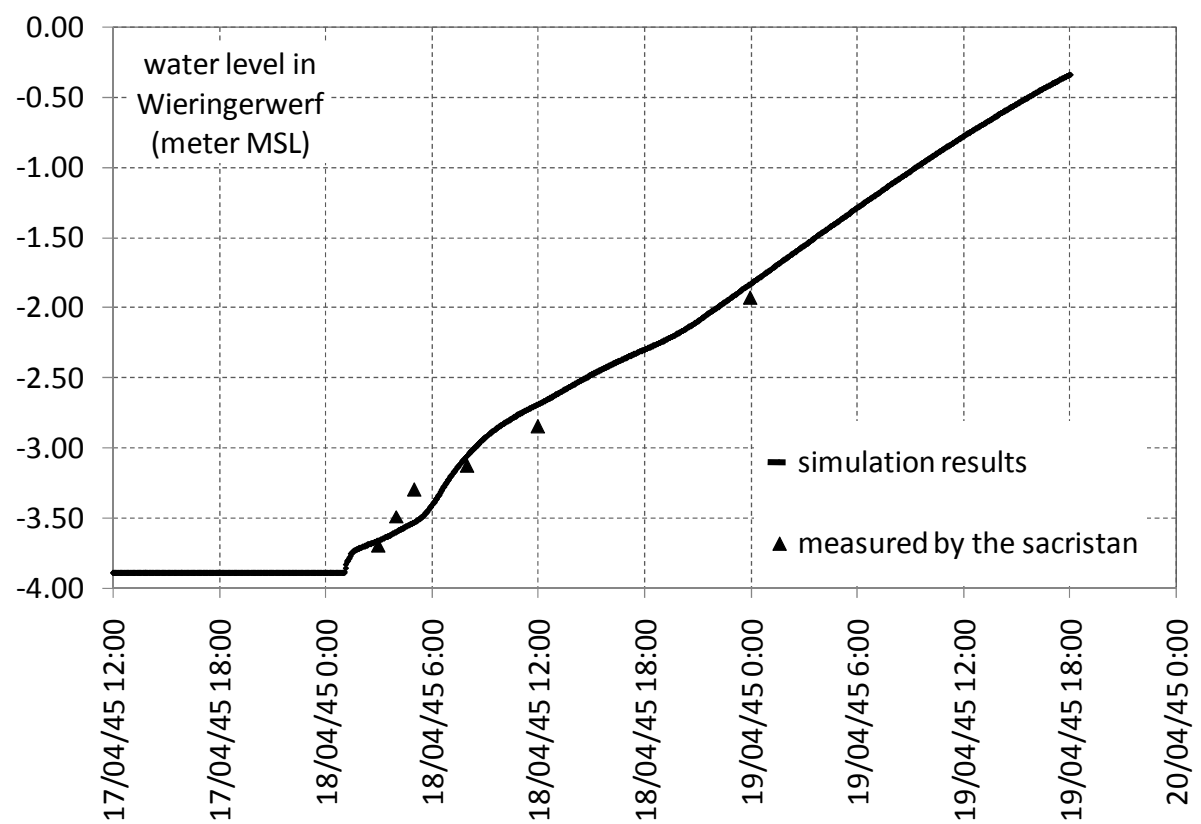

Fig. 6. Simulated water level rise in Wieringerwerf and historical measurements by the sacristan in the vicarage.

\section{NHESSD}

$1,417-441,2013$

\section{Reconstruction of the 1945 \\ Wieringermeer Flood}

O. A. C. Hoes et al.

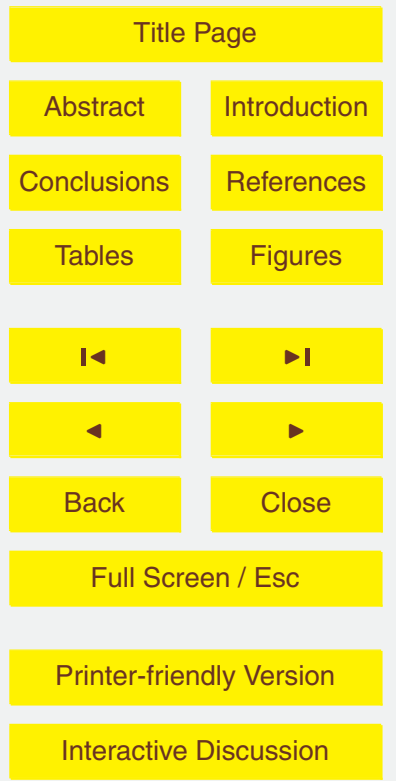




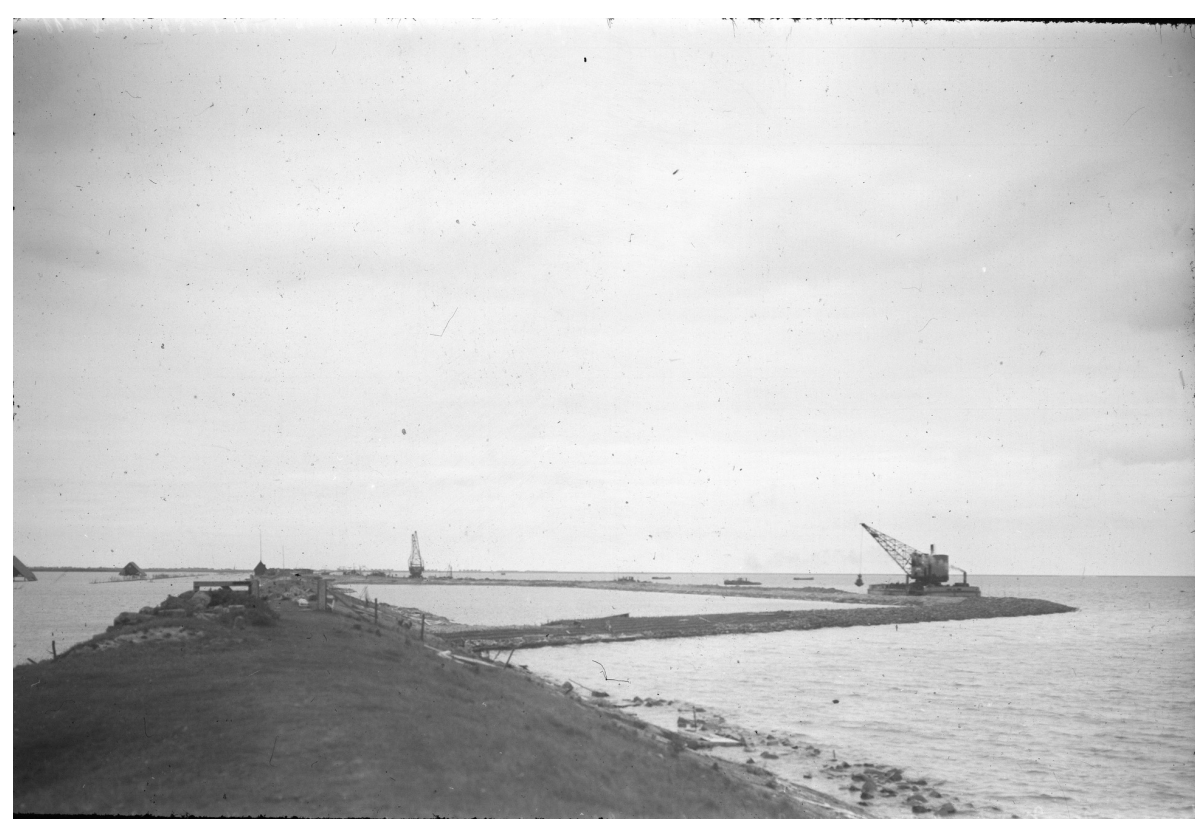

Fig. 7. Reconstruction works around the breach in August 1945. The polder is on the left with some roofs of farm houses visible in this picture and Lake IJssel is on the right.

\section{NHESSD}

$1,417-441,2013$

\section{Reconstruction of the 1945}

Wieringermeer Flood

O. A. C. Hoes et al.

\begin{tabular}{|c|c|}
\hline \multicolumn{2}{|c|}{ Title Page } \\
\hline Abstract & Introduction \\
\hline Conclusions & References \\
\hline Tables & Figures \\
\hline I4 & \\
\hline Back & Close \\
\hline Full Screen / Esc \\
\hline Printer-friendly Version \\
\hline Interactive Discussion
\end{tabular}




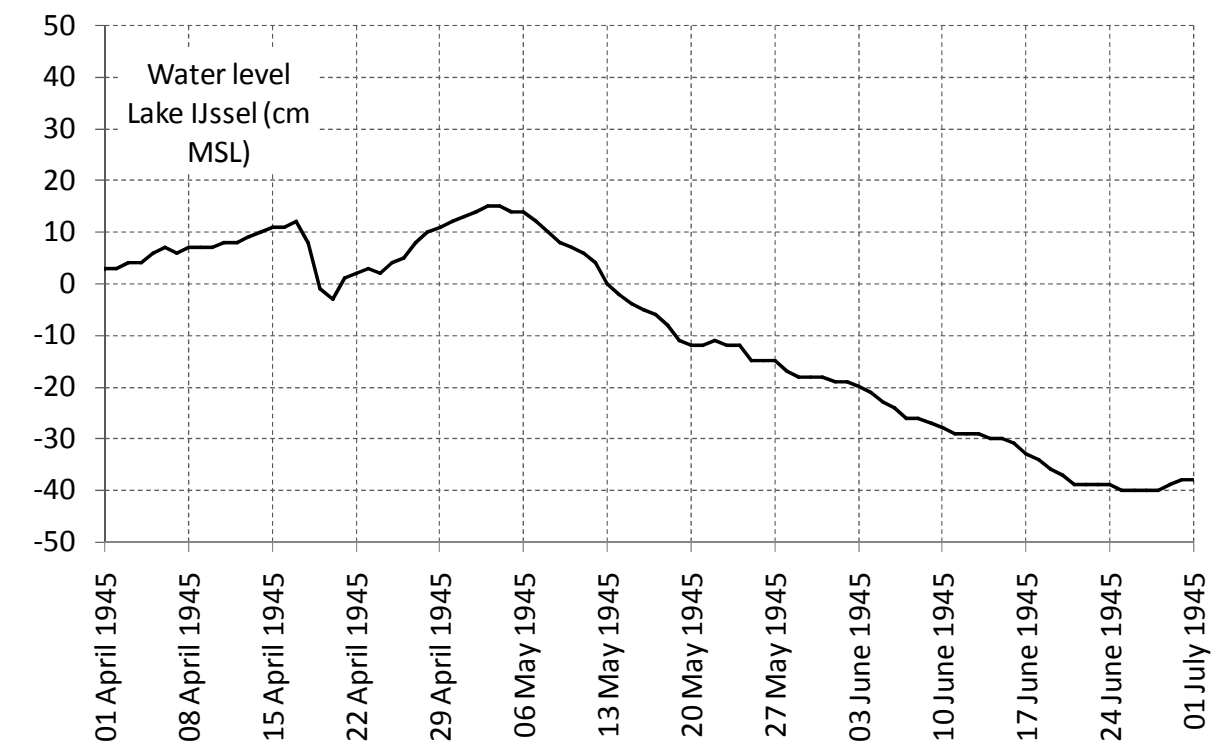

Fig. 8. Water level at Lake IJssel April-June 1945. On 17 April the water level was $+12 \mathrm{~cm}$ m.s.l. The water level dropped $15 \mathrm{~cm}$ between the 17 and the 20 April.

\section{NHESSD}

$1,417-441,2013$

\section{Reconstruction of the 1945 \\ Wieringermeer Flood}

O. A. C. Hoes et al.

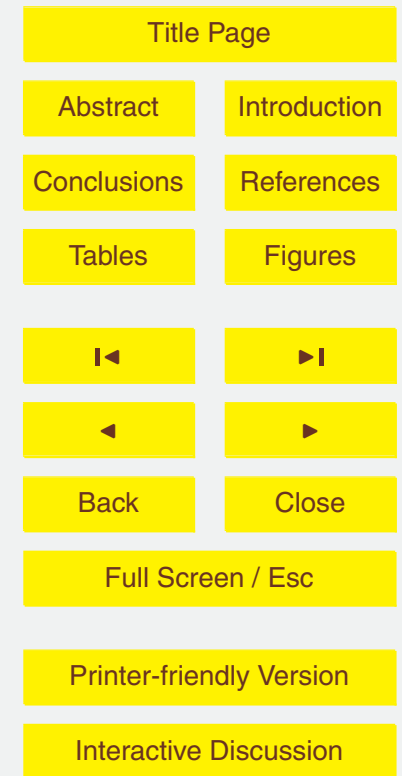

